\title{
IMPROVING THE STUDENTS' SPEAKING ABILITY THROUGH CASE PRESENTATION METHOD
}

\author{
Meningkatkan Kemampuan Berbicara Mahasiswa Melalui Presentasi Kasus \\ Dzur Rif'ah Mahmuda \\ English Education Department, Faculty of Teacher Training and Education \\ Muhammadiyah University of Makassar
}

\begin{abstract}
The research aimed at finding out the improvement of students' speaking ability through Case Presentation at the eleventh grade of SMA Negeri 1 Libureng Bone. The method of this research was classroom action research that consisted of two cycles. One cycle consisted of four meetings. It means that there were eight meeting in two cycles. This classroom action research was done at SMA Negeri 1 Libureng Bone for English subject. The subject research was 39 students of senior high school in 2012-2013 academic years. Those consist of 26 women and 13 men. Instruments are speaking test and observation sheet. The findings of this research were the improvement of the students' speaking ability in terms of speaking accuracy and speaking fluency in which the mean score of diagnostic test was 5.30, the mean score of cycle I was 6.27 and the mean score of cycle II was 7.29. The result above indicated that there was significant improvement of the students' speaking ability in terms of speaking accuracy and speaking fluency in the application of case presentation method at the eleventh grade of SMA Negeri 1 Libureng Bone.
\end{abstract}

Keywords: case presentation, speaking

The most important language being used among countries, institutions and individuals all over the world in the era of globalization is English. Therefore, English has come to be considered globally as the international language. John E. Joseph (2001) cites that some have asserted that it is far from inevitable that the spread of English will continue. However unstoppable it may appear at present, and educational systems need to prepare for this eventuality.

English is a language as a means of communication requires a habit of practice. Therefore, speaking is one of the skills that becomes a priority for all people especially learners of English to learn. Students express their thoughts in speaking but the fact shows that they sometimes find themselves bereft and absolutely it gives bad impact to the English learning process. For this reason, the researcher wants to emphasize on Improving the Speaking Proficiency in the English learning process.

According information the english teacher of SMA Negeri 1 Libureng Bone researcher consider a phenomenon among the students of SMA Negeri 1 Libureng Bone especially at the eleventh grade That, almost every one of them 
wishes to speak, but they found themselves difficult and even bereft to express it. It is because they do not have knowledge about grammar and vocabulary means the students were difficult to give question correctly concern with WH-Questions with the auxiliary verb in simple present form. Students are complicated to connect the subject with suitable auxiliary and also they are lack in vocabulary especially regular verb when they are speaking that actually can lead them from accuracy to fluency.

Besides the problems above the method that the English teacher applies in teaching English is conventional or not effective. The students are provided a piece of paper which contain of a dialogue then they memorize and practice it in front of the class. This way makes students monotonous because they are demanded to focus on the text. Considering to the reasons above, then the researcher focuses his attention on the speaking proficiency as one of the skills of language.

\section{Definition of Case Method}

According to Smith G. (1987:14) states that the term case teaching in this context refers to a description of a situation which exists or existed within an organization. In the other side Barners L.B., Christensen C.R., Hansen A.J., (1994:14) cite that a teaching case is description of episodes' of practice, a selection of reality, a slice of life, a story designed and presented as study material, an exercise, a puzzle, or a problem.

The case method is a teaching approach that consists in presenting the students with a case, putting them in the role of a decision maker facing a problem (Hammond in Hamka, 2011:5) The case method is a form of learning where the students first read a description of a real case or a problem taken from their occupational area. The description can be 2-50 pages and can sometimes include a video etc. The students elaborate on what to do in this case or how to solve this problem. After that they meet with the class and discuss the case with one another.

A case is typically written as a semi-story, told by case protagonists. But a story is always an interpretive account; there are inevitable gaps between reality, 
experience, and expression (Bruner in Hamka, 2011:5). Truthful representation of reality is made even more difficult by the limited space for a typical teaching case. In this regard, writing a case is an artful and selective endeavor that involves "a good deal of bold assertion and immodest neglect” (Maanen, Manning \& Miller, 1989: 5).

Relating to the definition above researcher concludes that case is a situation, a selection of reality that happen in environment which need to be resolved. The other hand case is a problem that comes from the causal relationship based on facts that accurate.

\section{Definition of Presentation}

Cunningsworth (1984:34) states that presentation is the initial stage of learning a new item. The teacher provides the new information, the new piece of knowledge, and the students concentrates on understanding it and remembering it. Although students may not seem to be doing very much overtly at this stage. The students are in fact very active mentally as students seek to understand and internalise the new rule which is being presented.

To make clear before giving more information about presentation, first of all, let's define what researcher means by "presentation":

a. (Essberger in Hamka, 2011:6) defines' that presentation as a short talk by one person to a group of people introducing and describing a particular subject (for example: a new product, company figures or a proposed advertising campaign)

b. Presentation is something that is presented specific. Making students speak is the problem of most of teacher. Teacher should always look for new ways to encourage their students to practice their oral English spontaneously. (Essberger in Hamka, 2011:7) states that " asking students to give presentation has the follow advantages: a) it gives the presenting students a good opportunity to practice unaided speaking, b) it gives the other students good listening practice, c) it increases the presenting students' competence when using English, d) It can be good practice for the real situation for those 
students who may actually need to give presentation in English in their professional lives, e) it is an excellent generator of spontaneous discussion".

Based on the definition above researcher can conclude that presentation is a chance where students delivering one point of information through describing a particular situation. Furthermore, doing presentation will lead the students into a professional speaking. Presentation also giving a chance for students to explore their ability in English dealing with their speaking ability.

\section{Definition of Case Presentation Method}

Refers to both of case and presentation definition above, the researcher concludes that Case Presentation is a short talk by one person or some people to deliver a news in class presentation form where the content is about a problem based on the facts that accurate for getting resolution. Case Presentation is really a right method to develop the students' Speaking ability because Case Presentation Method shows that teacher requires not only knowledge of subject matter, but knowledge of how students learn and how to transform them into active learners. It can also improve students' listening ability in additions for speaking ability. In addition, this is an interesting method for students to practice their English, because they are free to choose a case what they like to present as their interest.

\section{The Teaching Process of Case Presentation Method}

Barner (1994:26) state that learning cycle model people learn constantly cycling through the four stages of active experimentation, concrete experience, reflective observation and abstract conceptualisation. Can be seen as follows: (1). In the first cycle learners receive the case teaching or the case can be provided by the studentself.(2). The learners review the case.(3). Reflect and analysis the data presented in it. (4). Learners then are asked to reach conclusion about the case.

\section{The Advantage of Case Presentation Method}

According to Foran $(2002: 45)$ that the goal of the case presentation method include developing critical thinking skill, learning through decision-making and role-playing situation, developing confidence in defining and solving problem 
through interactive discussion and exercising and developing skill in public speaking and group problem solving.

The researcher can say that case presentation method is a great way to achieve the students' competence in speaking especially in accuracy and fluency competence through presentation. In other word students is not only focused in one skill through this method but students can improve another skill which is very helpful for their speaking improvement. Besides that Case Presentation Method has been used at Harvard university and many other universities for more than 50 years, mostly within business and law studies. During the 1980s and 1990s many universities and subject areas have adopted this method.

\section{RESEARCH METHODOLOGY}

\section{A. Research Type}

The method that used in this research was a classroom action research (CAR). It was conducted through two cycles to observe the students' ability to speak English through the application of case presentation method in teaching and learning process. The classroom action research consisted of planning, action, observation and reflection.

\section{B. Research Instrument}

In this research there were three main instruments which were used to collect the data, they were observation sheet, Speaking test and Cell phone recorder. The functions of observation sheet observation sheet aimed to find out the students' data about their presence and activeness in learning process. Speaking test aimed to get information about students' speaking improvement after teaching and learning process by using Case Presentation Method. Cell phone recorder aimed to measure the students' speaking fluency dealing with smoothness in learning process by using Case Presentation Method.

\section{Procedure of Collecting Data}

The procedure of collecting data in this classroom action research includes Observation sheet, Speaking test, and Cell phone recorder.

\section{Observation Sheet}


The researcher observed the students' activities in following teaching and learning process in the class to find out the students' data about their presence and activeness in teaching learning process.

\section{Speaking Test}

The researcher gave speaking test to the students in order to know their improvement. The type of speaking test which used in this research is observing form. The researcher divided the students into pair and ask to speak about material that they have learnt as well as grammatical.

\section{Cell phone recorder}

The researcher used cell phone recorder to measure the students' speaking fluency dealing with smoothness. The researcher records students' speaking every meeting in learning process by using Case Presentation Method and measure it after class.

In scoring the result of students' test were evaluated based on two aspects speaking below:

4. The assessment of speaking accuracy consists into grammar, and vocabulary.

Table 1 : Vocabulary

\begin{tabular}{|l|l|l|}
\hline \multicolumn{1}{|c|}{ Classification } & \multicolumn{1}{|c|}{ Score } & \multicolumn{1}{c|}{ Criteria } \\
\hline Excellent & $9.6-10$ & They speak effectively and excellent of using vocabulary \\
\hline Very good & $8.6-9.5$ & They speak effectively and very good of using vocabulary \\
\hline Good & $7.6-8.5$ & They speak effectively and good of using vocabulary \\
\hline Fairly good & $6.6-7.5$ & They speak sometimes hasty but fairly good of using vocabulary \\
\hline Fair & $5.6-6.5$ & They speak sometimes hasty, fair of using vocabulary \\
\hline Poor & $3.6-5.5$ & $\begin{array}{l}\text { They speak hasty, and more sentences are not appropriate using } \\
\text { vocabulary }\end{array}$ \\
\hline Very poor & $0.0-3.5$ & $\begin{array}{l}\text { They speak very hasty, and more sentences are not appropriate using } \\
\text { vocabulary and little or no communication. }\end{array}$ \\
\hline
\end{tabular}

Table 2 : Grammar

\begin{tabular}{|l|l|l|}
\hline \multicolumn{1}{|c|}{ Classification } & \multicolumn{1}{|c|}{ Score } & \multicolumn{1}{c|}{ Criteria } \\
\hline Excellent & $9.6-10$ & They speak effectively and excellent of grammar \\
\hline Very good & $8.6-9.5$ & They speak effectively and very good of grammar \\
\hline Good & $7.6-8.5$ & They speak effectively and good of grammar \\
\hline Fairly good & $6.6-7.5$ & They speak sometimes hasty but fairly good grammar \\
\hline Fair & $5.6-6.5$ & They speak sometimes hasty, fair of grammar \\
\hline Poor & $3.6-5.5$ & $\begin{array}{l}\text { They speak hasty, and more sentences are not appropriate in } \\
\text { grammar }\end{array}$ \\
\hline
\end{tabular}




\begin{tabular}{|l|l|l|}
\hline Very poor & $0.0-3.5$ & $\begin{array}{l}\text { They speak very hasty, and more sentences are not appropriate in } \\
\text { grammar and little or no communication }\end{array}$ \\
\hline
\end{tabular}

1) Tables of speaking fluency:

(Layman,1972: 218)

Table 3: Smoothness

\begin{tabular}{|c|c|l|}
\hline Classification & Score & \multicolumn{1}{|c|}{ Criteria } \\
\hline Excellent & $9.6-10$ & Their speaking is very understandable and high of smoothness. \\
\hline Very good & $8.6-9.5$ & Their speaking is very understandable and very good of smoothness. \\
\hline Good & $7.6-8.5$ & They speak effectively and good of smoothness. \\
\hline Fairly Good & $6.6-7.5$ & They speak sometimes hasty but fairly good of smoothness \\
\hline Fair & $5.6-6.5$ & They speak sometimes hasty, fair of smoothness \\
\hline Poor & $3.6-5.5$ & $\begin{array}{l}\text { They speak hasty and more sentences are not appropriate in } \\
\text { smoothness }\end{array}$ \\
\hline Very poor & $0.0-3.5$ & $\begin{array}{l}\text { They speak very hasty and more sentences are not appropriate in } \\
\text { smoothness and little or no communication }\end{array}$ \\
\hline
\end{tabular}

(Layman, 1972: 219)

\section{A. Technique of Data Analysis}

In assessing the students' progression during learning speaking material through Case Presentation Method, the researcher uses speaking assessment of speaking accuracy. The assessment divided in two categories; they were the assessment of students' accuracy and fluency in speaking. Each assessment has different criteria. These assessments consider being very important in speaking skill due to quite complex with other skills.

The data on the students' speaking ability in terms of accuracy and fluency were analyzed in the following procedures:

1. To find out the mean score of the students' test, the researcher used the formula :

$\bar{X}=\frac{\sum X}{N}$

Where :

$\bar{X} \quad=$ Mean Score

$\sum X \quad=$ Total Score

$N \quad=$ The number of students (Gay, 1981:289).

2. To classify the students' score, there were seven classifications which were used as follows:

a. 9.6-10 as excellent 
b. $8.6-9.5$ as very good

c. $7.6-7.5$ as good

d. $6.6-7.5$ as fairly good

e. $5.6-6.5$ as fair

f. $4.6-5.5$ as poor

g. $0-3.5$ as very poor (Depdikbud in Hamka, 2011:25).

\section{FINDINGS AND DISCUSSION}

This chapter consists of findings of the research and its discussion. The findings of the research presents the result of the students' improvement in speaking ability that covers the students' speaking accuracy and the students' speaking fluency toward the application of case presentation method, and the discussion of the research covers further explanation of the findings.

\section{A. Findings}

\section{The Improvement of the Students' Speaking Accuracy}

The application of case presentation method in improving the students' speaking ability covers speaking accuracy dealing with vocabulary and grammar at The Eleventh Grade of SMA Negeri 1 Libureng Bone can be seen clearly in the following table:

Table 4 : The Improvement of the Students' Speaking Accuracy

\begin{tabular}{|c|c|c|c|c|c|c|}
\hline \multirow{2}{*}{ Indicators } & \multicolumn{3}{|c|}{ The Students' Score (\%) } & \multicolumn{3}{c|}{ Improvement (\%) } \\
\cline { 2 - 7 } & D- Test & Cycle I & Cycle II & DT-CI & CI-CII & DT-CII \\
\hline Grammar & 5.34 & 6.28 & 7.40 & 0.94 & 1.12 & 2.06 \\
\hline Vocabulary & 5.45 & 6.37 & 7.36 & 0.92 & 0.99 & 1.91 \\
\hline$\sum_{X} X$ & 10.79 & 12.65 & 14.76 & 1.86 & 2.11 & 3.97 \\
\hline$X$ & 5.39 & 6.32 & 7.38 & 0.93 & 1.06 & 1.99 \\
\hline
\end{tabular}

The table above shows that the case presentation method improves the students' speaking accuracy from diagnostic test to cycle I and cycle II. In which cycle II is the highest among cycle I and diagnostic test. The mean score of the students' speaking accuracy in cycle II gets 7.38 or fairly good, highest among cycle I and diagnostic test where the students get 6.32 or fair in cycle I and the students get 5.39 or poor in diagnostic test of speaking accuracy. It indicates that the improvement of the students' speaking accuracy is 0.98 in diagnostic test to cycle I, the improvement in cycle I to cycle II is 1.06 , and the improvement in 
diagnostic test to cycle II is 1.99 . It indicates that it improves significantly through case presentation method

The table above proves that the use of case presentation method in theaching learning process is able to improve the students' speaking accuracy after action in cycle I and cycle II in which the students' achievement in cycle II is the highest (Cycle II $>$ Cycle I $>$ Diagnostic-Test) and the improvement of students' speaking accuracy from diagnostic test to cycle II is 1.99 .

To see clearly the improvement of the students' speaking accuracy, look at the following chart:

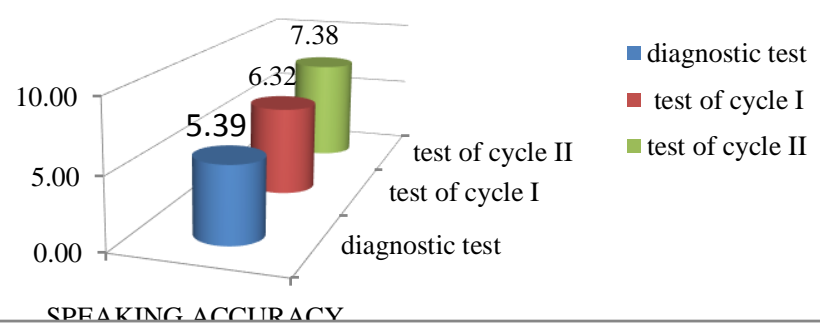

Figure 1: The Improvement of the Students' Speaking Accuracy

The chart above shows that the students' speaking accuracy in diagnostic test is 5.39 and the cycle $\mathrm{I}$ is 6.32 fewer than cycle II that is 7.39 and after evaluation in the cycle II the improvement of the students' speaking accuracy is 1.99 from diagnostic test $(5.39<6.32<7.39)$. Therefore, the application of case presentation method improves the students' speaking accuracy, and the improvement is significant (poor $\rightarrow$ fair $\rightarrow$ fairly good).

\section{The Improvement of the Students' Speaking Fluency}

The improvement of the students' speaking fluency through case presentation method dealing with smoothness by using test at The Eleventh Grade of SMA Negeri 1 Libureng Bone can be seen clearly in the following table:

Table 5: The Improvement of the Students' Speaking Fluency

\begin{tabular}{|l|c|c|c|c|c|c|}
\hline \multirow{2}{*}{ Indicators } & \multicolumn{3}{|c|}{ The Students' Score (\%) } & \multicolumn{3}{c|}{ Improvement (\%) } \\
\cline { 2 - 7 } & D- Test & Cycle I & Cycle II & DT-CI & CI-CII & DT-CII \\
\hline Smoothness & 5.21 & 6.23 & 7.21 & 1.02 & 0.98 & 2 \\
\hline
\end{tabular}


The table above shows that case presentation method also improves the speaking fluency of the students from diagnostic test to cycle I and cycle II In which cycle II is highest among cycle I and diagnostic test. The mean score of the students' speaking accuracy in cycle II got 7.21 or Fairly good, higher among cycle I and diagnostic test where the students get 6.32 or fair in cycle I and the students get 5.21 or poor in diagnostic test of speaking fluency. It indicates that the improvement of the students' speaking fluency is 1.02 in diagnostic test to cycle I, the improvement in cycle I to cycle II is 0.98 , and the improvement in diagnostic test to cycle II is 2 . It indicates that it improves significantly through case presentation method.

To see clearly the improvement of the students' speaking fluency, look at the following chart:

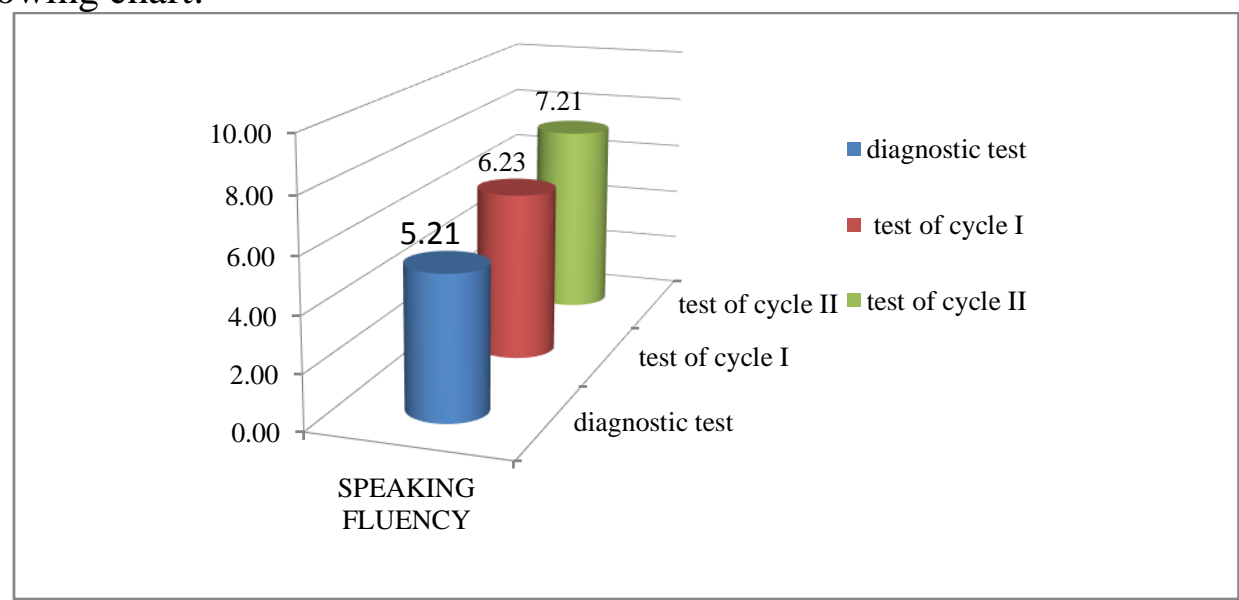

Figure 2: The Improvement of the Students' Speaking Fluency

The chart above shows that the students' speaking fluency in diagnostic test is 5.21 and the cycle I is 6.23 fewer than cycle II that is 7.21 and after evaluation in the cycle II the improvement of the students' speaking fluency is 2 from diagnostic test $(5.21<6.23<7.21)$. Therefore, the use of case presentation method improves the students' speaking fluency, and the improvement is significant (poor $\rightarrow$ fair $\rightarrow$ fairly good).

\section{The Improvement of the Students' Speaking Ability}

The application of case presentation method in improving the students' speaking ability covers speaking accuracy and fluency at The Eleventh Grade of SMA Negeri 1 Libureng Bone can be seen clearly in the following table: 
Table 6 : The Improvement of the Students' Speaking ability

\begin{tabular}{|c|c|c|c|c|c|c|}
\hline \multirow{2}{*}{ Indicators } & \multicolumn{3}{|c|}{ The Students' Score (\%) } & \multicolumn{3}{c|}{ Improvement (\%) } \\
\cline { 2 - 7 } & D- Test & Cycle I & Cycle II & DT-CI & CI-CII & DT-CII \\
\hline Accuracy & 5.39 & 6.32 & 7.38 & 0.93 & 1.06 & 1.99 \\
\hline Fluency & 5.21 & 6.23 & 7.21 & 1.02 & 0.98 & 2 \\
\hline$\sum X$ & 10.60 & 12.55 & 14.59 & 1.95 & 2.04 & 3.99 \\
\hline$X$ & 5.30 & 6.27 & 7.29 & 0.97 & 1.02 & 1.99 \\
\hline
\end{tabular}

The table above shows that case presentation method improves the students' speaking ability from diagnostic test to cycle I and cycle II In which cycle II is highest among cycle I and diagnostic test. The mean score of the students' speaking ability in cycle II get 7.29 or Fairly good, highest among cycle I and diagnostic test where the students get 6.27 or fair in cycle I and the students get 5.30 or very poor in diagnostic test of speaking ability. It indicates that the improvement of the students' speaking ability is 0.97 in diagnostic-test to cycle I the improvement in cycle I to cycle II is 1.02 , and the improvement in diagnostic test to cycle II is 1.99 It indicates that it improves significantly through case presentation method.

The table above proves that the use of case presentation method in teaching learning process is able to improve the students' speaking ability after action in cycle I and cycle II in which the students' improvement in cycle II is the highest (Cycle II $>$ Cycle I $>$ Diagnostic Test) and the improvement of students' speaking ability from diagnostic test to cycle II is 1.99 . To see clearly the improvement of the students' speaking accuracy, look at the following chart:

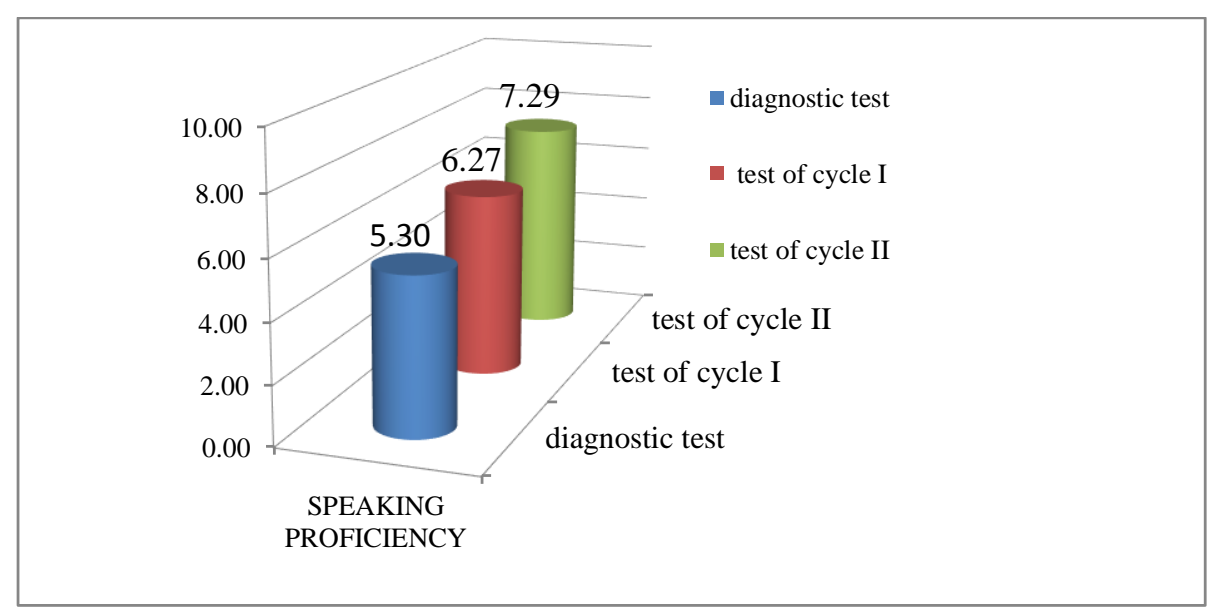

Figure 3: The Improvement of the Students' Speaking Ability 
The chart above shows that the students' speaking ability in diagnostic test is 5.30 and the cycle I is 6.27 fewer than cycle II is 7.29 and after evaluation in the cycle II the improvement of the students' speaking ability is 1.99 from diagnostic test $(5.30<6.27<7.29)$. Therefore, the use of case presentation method improves the students' speaking ability, and the improvement is significant (very poor $\rightarrow$ fair $\rightarrow$ fairly good).

\section{The Improvement of the Students' Activeness in Teaching Learning Process}

The application of case presentation method in improving the students' activeness in teaching learning process at The Eleventh Grade of SMA Negeri 1 Libureng Bone can be seen clearly in the following table:

Table 4: The Observation Result of the Students' Activeness in Teaching And Learning Process.

\begin{tabular}{|c|c|c|c|c|}
\hline Cycles & Meetings & Percentages & Averages & Improvement \\
\hline I & I & $44.23 \%$ & $50.47 \%$ & \\
& II & $47.43 \%$ & $5.43 \%$ \\
& III & $53.84 \%$ & & \\
& IV & $56.41 \%$ & & \\
& V & $58.97 \%$ & $68.90 \%$ & \\
& VI & $66.02 \%$ & & \\
& VII & $73.07 \%$ & & \\
& VIII & $77.56 \%$ & & \\
\end{tabular}

The table above explains that the average of the students' activeness in teaching and learning process through observation sheet by observer. The table above shows the process the students' activity in each meeting. The percentages of the cycle I from the first meeting to the fourth meeting are $44.23 \% 47.43 \%$ $53.84 \%$ and $56.41 \%$. Moreover, the percentage of the cycle II from the first meeting to the fourth meeting are $58.97 \% 66.02 \%, 73.07 \%$ and $77.56 \%$. In addition, the average score in every cycle, in cycle I is $50.47 \%$ and in cycle II is $68.90 \%$. From that, the improvement of the students' activity is $18.43 \%$. To know the improvement clearly, look at the following chart: 


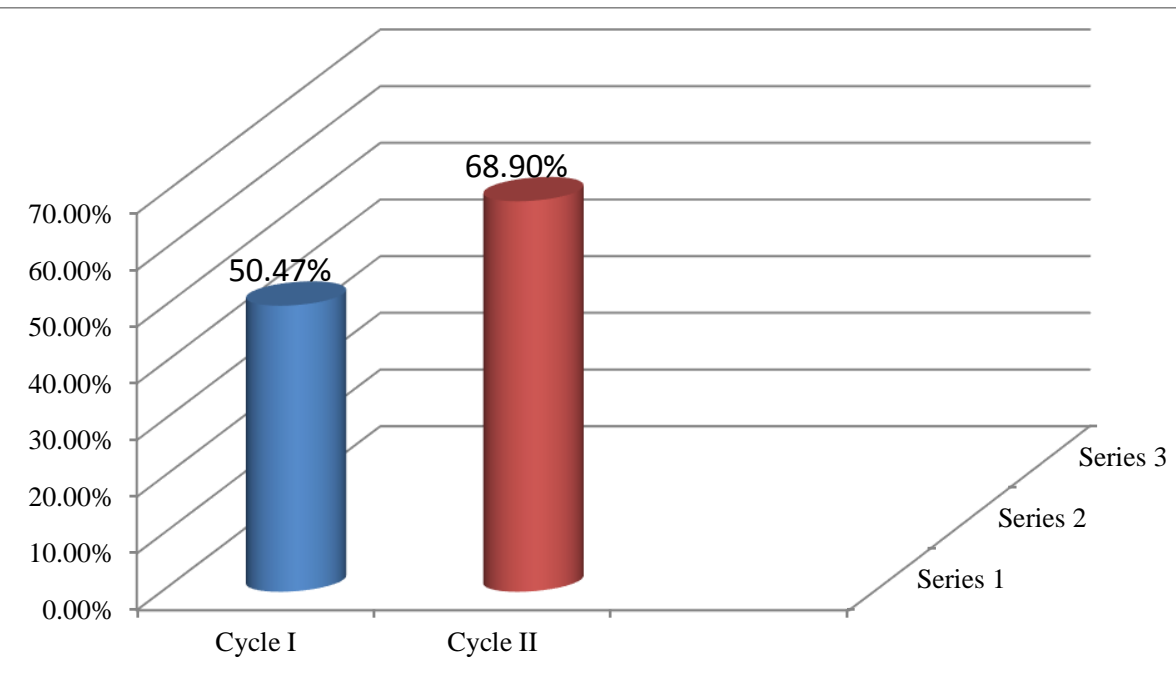

The chart above shows the students' observation in learning speaking by the application of case presentation method at The Eleventh Grade of SMA Negeri 1 Libureng Bone. In chart above, presents the students' situation during teaching learning process in speaking from cycle I to the cycle II. From the graphic it is known that there is changing of students' situation learning from cycle I to cycle II. The students' participation in learning speaking is fair within the mean score $50.47 \%$ and the changed to be $68.90 \%$. From that, the improvement of the students' activity from cycle I to cycle II is $18.43 \%$.

\section{B. Discussion}

\section{The Improvement of the Students' Speaking Accuracy Dealing With Vocabulary And Grammar.}

a. Vocabulary

The application of case presentation method in improving the students' speaking accuracy in terms of vocabulary can be seen the difference by considering the result of the students' diagnostic test and the students' improvement after taking action in cycle I and cycle II through the application of case presentation method in teaching learning process. The improvement of the students' speaking vocabulary through case presentation method had effective method. The reseacher finds that before the application of case presentation method the students score is $5.45 \%$ but after application the method the students' 
score in cycle I is $6.37 \%$ and in the cycle II became $7.36 \%$ so the improvement of the students score of the diagnostic test and cycle I is $0.92 \%$ whereas the improvement of the students' achievement of diagnostic test and cycle II was 1.91 $\%$. During the teaching and learning process in cycle I, the researcher finds that the students are difficult to speak in a correct vocabulary it causes by their language still influence by mother tongue and most of them do not have vocabulary stock for delivering their ideas. To solve this problem the researcher has done cycle II and revise the previous lesson plan, give them deep explanation and repeated the word still they can get it.

From the explanation above the researcher analyzes that the method of case presentation method can improve students' speaking vocabulary where the students mean score in cycle I and cycle II are higher than D test. To see clearly the improvement of the students' vocabulary in speaking look at the following table:

Table 7: The percentage of the students' vocabulary in speaking

\begin{tabular}{|c|c|c|c|c|c|c|c|c|}
\hline \multirow{3}{*}{ No } & \multirow{3}{*}{ Classification } & \multirow{3}{*}{ Range } & \multirow{2}{*}{\multicolumn{2}{|c|}{$\begin{array}{c}\text { Non CP } \\
\text { D-test }\end{array}$}} & \multicolumn{4}{|c|}{ The Application of Case Presentation } \\
\hline & & & & & \multicolumn{2}{|c|}{ Cycle I } & \multicolumn{2}{|c|}{ Cycle II } \\
\hline & & & Freq & $\%$ & Freq & $\%$ & Freq & $\%$ \\
\hline 1 & Excellent & $9.6-10$ & 0 & 0 & 0 & 0 & 0 & 0 \\
\hline 2 & Very good & $8.6-9.5$ & 0 & 0 & 0 & 0 & 7 & 17.49 \\
\hline 3 & Good & $7.6-8.5$ & 0 & 0 & 3 & 7.69 & 15 & 38.46 \\
\hline 4 & Fairly good & $6.6-7.5$ & 5 & 12.82 & 9 & 23.07 & 17 & 43.58 \\
\hline 5 & Fair & $5.6-6.5$ & 7 & 17.94 & 18 & 46.15 & 0 & 0 \\
\hline 6 & Poor & $3.6-5.5$ & 26 & 66.66 & 9 & 23.07 & 0 & 0 \\
\hline 7 & Very poor & $0-3.5$ & 1 & 2.56 & 0 & 0 & 0 & 0 \\
\hline \multicolumn{3}{|c|}{ Total } & 39 & 100 & 39 & 100 & 39 & 100 \\
\hline
\end{tabular}

The scores are acquired from the presentation of data analysis, and the improvement is presented in higher number of the students to show that the improvement is significant such as: in diagnostic test, 1 student $(2.56 \%)$ gets very poor, 26 students $(66.66 \%)$ get poor, 7 students $(17.94 \%)$ get fair, and 5 students $(12.82 \%)$ get fairy good (table 7). It improves after taking cycle I where 9 students $(23.07 \%)$ get poor, 18 students $(46.15 \%)$ get fair, 9 students $(23.07 \%)$ get fairly good and 3 student (7.69\%) get good (table 7). In cycle II, it improves again where 17 students (43.58\%) get fairy good, 15 students (38.46\%) get good and 7 students (17.94\%) get very good (table 7). 
The percentage above shows that in the diagnostict test most of the students still speak hasty and more sentences are not appropriate using vocabulary and it is absolutely far from the score standard. So the researcher does cycle I where the number of the students who speak fair of using vocabulary still dominate. It means that the indicator has not achieved yet. So the researcher continues to the second cycle and through testing almost all students speak sometime hasty but fairly good of using vocabulary and it proves that the indicator has improved.

These score percentage above indicates that the application of case presentation method can improve the students' speaking accuracy in term of vocabulary. The vocabulary that students use when they are speaking is more varieties after giving action I and action II than before giving the action where the students' vocabulary when they are speaking is very limit. Based on the explanation above can be seen that the students speaking accuracy dealing with vocabulary improves significantly.

\section{b. Grammar}

The application of case presentation in improving the students' speaking ability in terms of grammar can be seen the difference by considering the result of the students' diagnostic test ( Non Case Presentation ) and the students' achievement after taking action in cycle I and II (The Application of Case Presentation ).

The improvement of the students' speaking grammar through case presentation method had effective method. The researcher found that before the application of case presentation method the students score was $5.34 \%$ but after application the method the students' score in cycle I was $6.28 \%$ and in the cycle II became $7.40 \%$ so the improvement of the students score of the D test and cycle I was $0.94 \%$ whereas the improvement of the students' achievement of D test and cycle II was $2.06 \%$.

During the teaching and learning process in cycle I, the researcher found that the students were difficult to speak in a correct grammar it caused by their language still influenced by mother tongue and most of them did not have knowledge about grammar for delivering their ideas. To solve this problem the 
researcher had done cycle II and revised the previous lesson plan, give them deep explanation related to what becomes problem that the students' faced.

From the explanation above the researcher analyzed that the method of case presentation method can improve students' speaking grammar where the students mean score in cycle I and cycle II was higher than D test. To see clearly the improvement of the students' grammar in speaking look at the following table:

Table 8: the percentage of the students' grammar in speaking.

\begin{tabular}{|c|c|c|c|c|c|c|c|c|}
\hline \multirow{2}{*}{ No } & \multirow{2}{*}{ Classification } & \multirow{2}{*}{ Range } & \multicolumn{2}{|c|}{ Non CP } & \multicolumn{4}{|c|}{ The Application of Case Presentation } \\
\cline { 4 - 9 } & & & \multicolumn{2}{|c|}{ D-test } & \multicolumn{2}{|c|}{ Cycle I } & \multicolumn{2}{c|}{ Cycle II } \\
\cline { 4 - 9 } & & & Freq & $\%$ & Freq & $\%$ & Freq & $\%$ \\
\hline 1 & Excellent & $9.6-10$ & 0 & 0 & 0 & 0 & 0 & 0 \\
\hline 2 & Very good & $8.6-9.5$ & 0 & 0 & 0 & 0 & 2 & 5.12 \\
\hline 3 & Good & $7.6-8.5$ & 0 & 0 & 3 & 7.69 & 7 & 17.94 \\
\hline 4 & Fairly good & $6.6-7.5$ & 3 & 7.69 & 7 & 17.94 & 16 & 41.02 \\
\hline 5 & Fair & $5.6-6.5$ & 7 & 17.94 & 17 & 43.58 & 14 & 35.89 \\
\hline 6 & Poor & $3.6-5.5$ & 27 & 69.23 & 12 & 30.76 & 0 & 0 \\
\hline 7 & Very poor & $0-3.5$ & 2 & 5.12 & 0 & 0 & 0 & 0 \\
\hline & Total & & 39 & 100 & 39 & 100 & 39 & 100 \\
\hline
\end{tabular}

The scores are acquired from the presentation of data analysis, and the improvement is presented in higher number of the students to show that the improvement is significant such as: in diagnostic test, 2 student $(5.12 \%)$ get very poor, 27 students $(69.23 \%)$ get poor, 7 students (17.94\%) get fair, and 3 students (7.69\%) get fairly good (table 8). It improves after taking cycle I where 12 students (30.76\%) get poor, 17 students (43.58\%) get fair, 7 students $(17.94 \%)$ get fairly good and 3 student (7.69\%) get good (table 8 ). In cycle II, it improves again where 14 students (35.89\%) got fair 16 students $(41.02 \%)$ get fairly good, 7 students (17.94\%) get good and 2 students $(5.12 \%)$ get very good (table 8$)$.

The percentage above shows that in the diagnostic test most of the students still speak hasty and more sentences are not appropriate in grammar and it is absolutely far from the score standard. So the researcher does cycle I where the number of the students who speak fair of grammar still dominate. It means that the indicator has not achieved yet. So the researcher continues to the second cycle and through testing almost all students speak fairly good of grammar and it proves that the indicator has improved. 
The score percentage above indicates that the application of case presentation method can improve the students' speaking accuracy in term of grammar, where the use of WH- Question is more clear and complete of the stucture when students are speaking. The percentage above also shows that the improvement of the students' grammar in speaking moves from the lower percent to the high percent and it absolutely proves that the students' grammar in speaking improves significantly.

\section{The Improvement of the Students' Speaking Fluency Dealing With Smoothness}

The application of case presentation method in improving the students' speaking fluency in term of smoothness can be seen the difference by considering the result of the students' D-test and the students' improvement after getting action in each cycles.

The improvement of the students' smoothness in speaking through case presentation method had effective method. The researcher found that before the application of case presentation method the students score was $5.21 \%$ but after application the method the students' score in cycle I was $6.23 \%$ and in the cycle II became $7.21 \%$ so the improvement of the students score of the D test and cycle I was $1.02 \%$ whereas the improvement of the students' achievement of D test and cycle II was $2 \%$.

During the teaching and learning process in cycle I, the researcher found that the students were difficult to speak fluently it caused by their language still influenced by mother tongue and most of them seldom speak in English which actually can help their fluency. To solve this problem the researcher had done cycle II and revised the previous lesson plan, give them more activity in speaking to train their fluency.

From the explanation above the researcher analyzed that the method of case presentation method can improve students' speaking smoothness in speaking where the students mean score in cycle I and cycle II was higher than D test. To see clearly the improvement of the students' vocabulary in speaking look at the following table: 
Table 9: The percentage of the students' speaking smoothness

\begin{tabular}{|c|c|c|c|c|c|c|c|}
\hline \multirow{3}{*}{ Classification } & \multirow{3}{*}{ Range } & \multirow{2}{*}{\multicolumn{2}{|c|}{$\begin{array}{c}\text { Non CP } \\
\text { D-test }\end{array}$}} & \multicolumn{4}{|c|}{ The Application of CP } \\
\hline & & & & \multicolumn{2}{|c|}{ Cycle I } & \multicolumn{2}{|c|}{ Cycle II } \\
\hline & & Freq & $\%$ & Freq & $\%$ & Freq & $\%$ \\
\hline Excellent & $9.6-10$ & 0 & 0 & 0 & 0 & 0 & 0 \\
\hline Very good & $8.6-9.5$ & 0 & 0 & 0 & 0 & 4 & 10.25 \\
\hline Good & $7.6-8.5$ & 1 & 2.56 & 4 & 10.25 & 7 & 17.49 \\
\hline Fairy good & $6.6-7.5$ & 6 & 15.38 & 7 & 17.94 & 19 & 48.71 \\
\hline Fair & $5.6-6.5$ & 7 & 17.94 & 16 & 41.02 & 9 & 23.07 \\
\hline Poor & $3.6-5.5$ & 22 & 56.41 & 12 & 30.76 & 0 & 0 \\
\hline Very poor & $0-3.5$ & 3 & 7.69 & 0 & 0 & 0 & 0 \\
\hline \multicolumn{2}{|c|}{ Total } & 39 & $100 \%$ & 39 & $100 \%$ & 39 & $100 \%$ \\
\hline
\end{tabular}

The scores are acquired from the presentation of data analysis, and the improvement is presented in higher number of the students to show that the improvement is significant such as: in diagnostic test, 3 students $(7.69 \%)$ got very poor, 22 students $(56.41 \%)$ get poor ,7 students (17.94\%) get fair 6 students $(15.38 \%)$ got fairly good, and 1 students $(2.56 \%)$ got good (table 9). It improves after taking cycle I where 12 students $(30.76 \%)$ get poor, 16 students $(41.02 \%)$ get fair, and 7 students (17.94\%) get fairly good and 4 students (10.25\%) (table 9). In cycle II, it improves again where 9 students (23.06\%) get fair, 19 students (48.71) get fairly good, 7 students (17.94\%) got good and 4 students $(10.25 \%)$ get very good (table 9).

The percentage above shows that in the diagnostict test most of the students still speak hasty and more sentences are not appropriate in smoothness and it is absolutely far from the score standard. So the researcher does cycle I where the number of the students who speak hasty and fair of smoothness still dominate. It means that the indicator has not achieved yet. So the researcher continues to the second cycle and through testing almost all students speak fairly good of smoothness and it proves that the indicator has improved. These score percentage above indicate that the application of case presentation method can improve the students' speaking fluency in term of smoothness and the improvement is significant.

\section{CONCLUSION AND SUGGESTION}

\section{A. Conclusion}


Based on the research findings and discussion in the previous chapter, the researcher draws conclusion that:

1. The students' speaking ability in terms of accuracy and fluency

The mean score of the students' speaking ability in diagnostic test was 5.30. It is categorized as very poor classification. While the mean score of the students' speaking test in cycle I is 6.27. It is higher than the mean score of the students' diagnostic test. But the result is not significant from the result which is expected according to the background namely 6.5. Cycle II and the mean score of the students' speaking test is 7.29. It indicates the significant score from the result expected in the background namely 6.5. The result above is acquired from the students' speaking ability in terms of speaking accuracy and speaking fluency.

a. The student's Speaking accuracy

1) Vocabulary

- The mean score of the students' diagnostic test $=5.45$

- $\quad$ The mean score of the students' speaking in cycle $\mathrm{I}=6.37$

- $\quad$ The mean score of the students' speaking in cycle II $=7.36$

2) grammar

- $\quad$ The mean score of the students' diagnostic test $=5.34$

- $\quad$ The mean score of the students' speaking in cycle $\mathrm{I}=6.28$

- $\quad$ The mean score of the students' speaking in cycle II $=7.40$

b. The students' Speaking fluency dealing with the Smoothness

- $\quad$ The mean score of the students' diagnostic test $=5.21$

- The mean score of the students' speaking test in cycle $\mathrm{I}=6.23$

- $\quad$ The mean score of the students' speaking test in cycle II $=7.21$

It proves that the application of case presentation method could significantly improve the students' speaking ability in terms of accuracy dealing with vocabulary, grammar and fluency dealing smoothness at The Eleventh Grade of SMA Negeri 1 Libureng Bone. 


\section{B. Suggestions}

In relation to the speaking ability in terms of accuracy and fluency, the researcher would like to give suggestions for English teacher, teachers should take advantage of case presentation method in speaking ability in terms of accuracy dealing with grammar at The Eleventh Grade of SMA Negeri 1 Libureng Bone.

\section{REFERENCES}

Bryne, Donn. 1987.Teaching Oral English. New Edition. New York: Longman Inc. Burgoyne, Jhon. 2001. Learning From The Case Method. North America: Lancaster University

Ellis, R. (2003). Task-based Language Learning and Teaching. Oxford: Oxford University

Foran, John. 2002. The Case Method and the Interactive Classroom. Amerika: University of California.

Garvin, David A. 2003. Making the Case. Professional education for the world of practice. http://harvardmagazine.com/2003/09/making-the-case-html [0n 20 July 2011 ]

Gay, L.R, 1981, Educational Research; Competencies for Analysis and Applications. Columbus: Charcks, E. Merril Publishing Co.

Hedge, T. (2000). Teaching and Learning in the Language Classroom. Oxford University Press.

Hornby. A.S. 1974. Oxford Advanced Learner's Dictionary of Current English. Third Edition. New York: Oxford University Press

Husock, Howard.1987. An Overview of the Case Method. Manhattan Institute http://www.ksgcase.harvard.edu/content/Teaching_Resources/Using_the Case Method.html [0n 20 July 2011]

Larsen - Freeman, D. 1987. Techniques and Principles In Language Teaching. Oxford: Oxford University

Nunan, D. (1998). Teaching Grammar in Context. ELT journal, 52, 101-109.

Scrivener, J. (1994a) PPP \& After. The Teacher Trainer 8/1 Press.

Sudjana.1999.Metode Statistika.Bandung.PT.Gramedia 
Swan, Michael.2005. Practical English Usage. Oxford University Press.

Wallace, C. 1988. Action Research for Teacher. Cambridge: Cambridge University Press. 